Karstenia 45: 69-72, 2005

\title{
Geastrum berkeleyi in the Åland Islands, SW Finland
}

\author{
RALF CARLSSON and CARL-ADAM HÆGGSTRÖM
}

\begin{abstract}
CARLSSON, R. \& HÆGGSTRÖM, C.-A. 2005: Geastrum berkeleyi in the Åland Islands, SW Finland. - Karstenia 45: 69-72. Helsinki. ISSN 0453-3402.

Geastrum berkeleyi Massee was found in NE Åland in 2004. The species has not been recorded earlier on Aland or in Finland. Several finds are known from the adjacent parts of Sweden, e.g. Uppland and especially Gotland. The species is rare in central and western Europe. The distribution of $G$. berkeleyi in the Nordic countries is briefly outlined and its ecology is discussed. The locality on Alland with the accompanying vascular plant flora and the soil properties is described. The properties which distinguish $G$. berkeleyi are discussed.
\end{abstract}

Key words: Åland Islands, calcium, soil, spores, vascular plant flora

Ralf Carlsson, Husö Biological Station (Åbo Akademi University), AX-22220 Emkarby, Åland, Finland. Correspondence address Högbackagatan 10, AX-22100 Mariehamn, Aland, Finland

Carl-Adam Haggström, Department of Biological and Environmental Sciences, P.O.Box 65 FI-00014 University of Helsinki, Finland

\section{Introduction}

The autumn of 2004 was extraordinarily good for fungi, including earthstars, in the Alland Islands. The author RC got knowledge of several localities with earthstars. Besides the three fairly common species Geastrum fimbriatum Fr., G. pectinatum Pers. and G. quadrifidum Pers. : Pers. and the very rare G. striatum DC. (Hæggström 1997a), two new localities of $G$. rufescens Pers. (Carlsson \& Hæggström 2005) and four new of G. triplex (cf. Hæggström \& Carlsson 1999) were found. On 29 September 2004, the species G. berkeleyi was found in the village of Bertby in the municipality of Saltvik, at about $60^{\circ} 21^{\prime} \mathrm{N}$ and $20^{\circ} 06^{\prime} \mathrm{E}$, in the NE part of the Aland Islands proper.

Geastrum berkeleyi is a rare and rather southerly species in the Nordic countries and the Baltic area (distribution chiefly according to Sunhede 1989). It has been found in more than 30 localities in the limestone island of Gotland, and ten localities are known in southern mainland Sweden, the northernmost in the coastal area of
Uppland at about $60^{\circ} \mathrm{N}$. The species has been found in 1960 near Copenhagen in Denmark (Sunhede 1989) and in 1967 in Kõpu peninsula in the island of Hiiumaa in Estonia (Järva 1999). It has not been found in Norway. Records, according to Sunhede (1989), are also known from former Czechoslovakia, Germany, England, Scotland, France, Spain and Turkey. The species seems to be rare in all parts of Europe.

Geastrum berkeleyi is not included in the Red List of Finland (Rassi et al. 2001) and Norway (NRL 2002). It is regarded as endangered in Denmark (DMS 2004) and vulnerable in Estonia (Järva 1999, ERL 2001-2002) and Sweden (Gärdenfors 2000).

\section{Material and methods}

The following material was studied: Alandia. Saltvik, Bertby, at a small house about $200 \mathrm{~m} \mathrm{~W}$ of the westernmost part of the bay of Bertbyvik, 3 ripe sporocarps collected, Grid. $27^{\circ}$ E: 67128:1191, 29 September 2004 Ralf Carlsson $(\mathrm{H})$. 
A WILD M 20 microscope was used for light microscopy. Spores were studied at $2250 \times$ magnification. Fifty spores from each sporocarp were measured in Melzer's reagent. The diameter of the spores including their processes could be measured with an accuracy of about $0.4 \mu \mathrm{m}$.

A soil sample from the humus layer was analysed at the laboratory of The Agri- and Horticultural Research Station of the Aland Islands. The sample was extracted for one hour in a solution of ammonium acetate $(\mathrm{pH}$ 4.65) and analysed for exchangeable $\mathrm{Ca}^{++}, \mathrm{Mg}^{++}, \mathrm{K}^{+}$and $\mathrm{PO}_{4}^{2-}$ with atomic absorption spectrophotometry. Further, the $\mathrm{pH}$ was measured on $25 \mathrm{ml}$ of dried and ground soil which was mixed with $62.5 \mathrm{ml}$ of ion-exchanged water. The measuring took place 17 hours later.

The nomenclature of the vascular plants is according to the Finnish Field Flora (Hämet-Ahti et al. 1998).

\section{Results}

\section{Sporocarps and spores}

The three sporocarps were distinguished as belonging to the species Geastrum berkeleyi due to the distinctly asperate endoperidium surface consisting of acute processes and short and sharp ridges (Fig. 1). Further, the apophysis, the long and densely plicate peristome and distinct peristome field of the endoperidium are typical features of this species.

The number of exoperidium rays was seven in all three sporocarps. The size of them varied as follows:

- width of expanded exoperidium: $69 \mathrm{~mm}-74$ $\mathrm{mm}$.

- size of endoperidium (diameter and the height from the base to the peristome base): diameter 15-20 mm, height 11-14 mm.

The spore size varied between 4.4 and $6.4 \mu \mathrm{m}$; the mean size of the spores of the three gastrocarps was 5.36, 5.34 and $5.50 \mu \mathrm{m}(\mathrm{n}=50)$.

\section{Description of the locality and accompanying vascular plant species}

The Bertby area in general is a hill landscape (60$70 \mathrm{~m}$ a.s.l.) with pine heath forest on rocky ground, dissected by small valleys and grooves with mixed forest and richer vegetation than on the hills. The

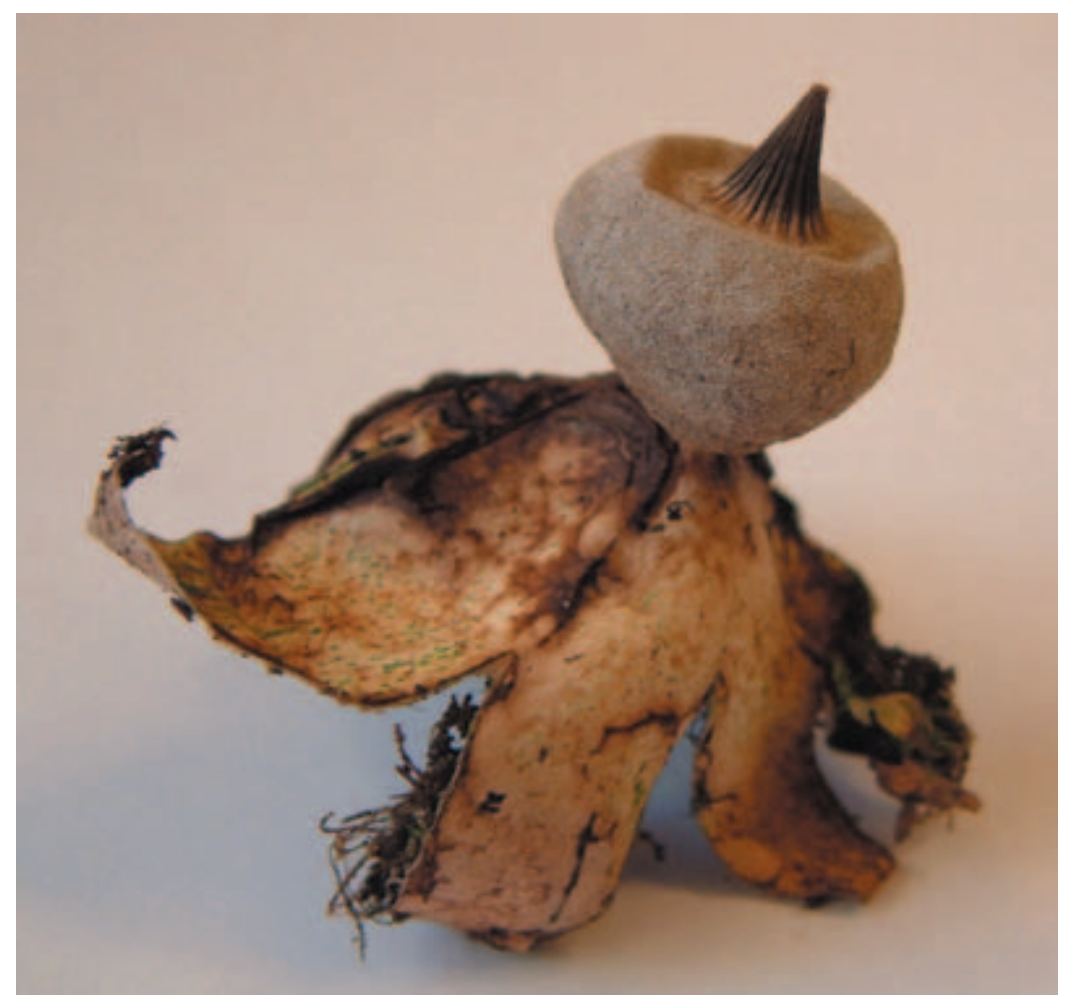

Fig. 1. One of the three sporocarps of Geastrum berkeleyi collected in Al, Saltvik, Bertbyvik. Photo: Ralf Carlsson. 
location of the G. berkeleyi is just to the north of the hill landscape in an old flower bed (rockery) in the backyard of a small house about $20 \mathrm{~m}$ from the main road. In the surroundings are open meadows and houses and about 20 metres from the flower bed is a small swamp, overgrown with young, mixed pine forest. About $200 \mathrm{~m}$ from the house, on the other side of the road, is the innermost part of the bay Bertbyvik. The elevation of the locality is between 5 and 10 metres a.s.1.

The following tree and shrub species grew in the vicinity: Acer platanoides, Betula pendula, Juniperus communis, Picea abies, Pinus sylvestris, Sorbus aucuparia and Viburnum opulus. The field layer comprised quite common species, such as Aegopodium podagraria, Anthriscus sylvestris, Calamagrostis epigejos, Carex digitata, Deschampsia flexuosa, Fragaria vesca, Geranium sylvaticum, Hepatica nobilis, Hieracium sp., Luzula pilosa, Oxalis acetosella, Pteridium aquilinum, Rubus idaeus, Taraxacum sp., Tussilago farfara, Urtica dioica and Vaccinium myrtillus.

\section{The soil}

The soil is a rather dry young humus soil typical of Åland. The following soil properties were measured:

- pH6.0

- $\mathrm{Ca}^{++} 4455 \mathrm{mg} / \mathrm{l}$

- $\mathrm{Mg}^{++} 281 \mathrm{mg} / \mathrm{l}$

- $\mathrm{K}^{+} 154 \mathrm{mg} / \mathrm{l}$

- $\mathrm{PO}_{4}^{2-} 42.3 \mathrm{mg} / \mathrm{l}$

\section{Discussion}

Five species of Geastrum with a stipitate endoperidial body, a plicate (or sulcate) peristome and a distinct peristome field have been found in the Nordic countries, namely G. berkeleyi, G. campestre Morgan, G. pectinatum Pers., G. schmidelii Vittad. and G. striatum DC. (Sunhede 1989, 1997). Of these, G. schmidelii and G. striatum have smooth endoperidia. Further, the ring-like collar of the apophysis which forms a sharp furrow is a very prominent distinguishing feature of G. striatum.

G. eastrum berkeleyi resembles most G. campestre and G. pectinatum. Of these, G. campestre is more or less hygroscopic. Further, its endoperidial body is usually smaller with a shorter stalk. Its spores are larger $(6.5-8.0 \mu \mathrm{m})$ than in the two oth- er species (5.5-7.0 (-7.5)) $\mu \mathrm{m}$; measurements according to Sunhede 1989).

Specimens of G. pectinatum often have an endoperidial body covered with a greyish rough material. However, the surface is only felted in patches, with low and rounded processes. The sharp and prominent processes and ridges of $G$. berkeleyi are lacking. Further, the peristome field is less prominent in G. pectinatum.

The endoperidial body of G. elegans Vitt., a species found once on Järsö in Lemland, Åland (Sunhede 1989, Hæggström 1997a), is sessile and a peristome field is lacking.

Sunhede $(1989,1997)$ reports that the spores are 5.5-7.0 (-7.5) $\mu \mathrm{m}$ in diameter. His measurements were made on spores examined with a light microscope in $2 \% \mathrm{KOH}$, Melzer's reagent and lactophenol with cotton blue. The size of the spores of our specimens measured in Melzer's reagent are somewhat smaller; the mean values are between 5.34 and $5.50 \mu \mathrm{m}$. However, the diameters of six spores in Sunhede's (1989) SEM Fig. 32 are only 4.52-5.13 $\mu \mathrm{m}$, and so accord with our measurements. In a study on Bovista pusilliformis (Kreisel) Kreisel (Hæggström 1997 b), the spores measured were on average larger in Melzer's reagent than in lactophenol, a feature also seen in other Lycoperdaceae spores. Spores measured on SEM photographs were even smaller. A similar result was also seen in the spores of Geastrum rufescens (Carlsson \& Hæggström 2005). Thus spores studied in liquid reagents are obviously larger than dry ones (Hæggström 1997b).

Geastrum berkeleyi has been found in the Nordic countries chiefly in coniferous and deciduous woods, under junipers in otherwise more or less open ground and on open grazed ground (Sunhede 1989). The habitat of the species, in an old flower bed, is also in accordance with Schwik et al. (1999) who regard it as a synanthropic species. According to Sunhede (1989), the $\mathrm{pH}$ (measured in a water suspension) in 16 localities with G. berkeleyi varied between 4.5 and 6.4 in the uppermost soil layer $(0-5 \mathrm{~cm})$, and between 6.2 and 7.2 in the soil immediately below $5 \mathrm{~cm}$. The pH-value 6.0 of our locality is in agreement with Sunhede's findings. The content of all measured nutrients $\left(\mathrm{Ca}^{++}\right.$, $\mathrm{Mg}^{++}, \mathrm{K}^{+}$and $\mathrm{PO}_{4}^{2-}$ ) is high (cf. Hæggström 1983, Hæggström \& Carlsson 1999, Carlsson \& Hæggström 2005). It seems that G. berkeleyi is a calciphilic species in the Åland Islands, in accordance with most Geastrum species. 
Acknowledgements: We are indebted to Mrs Krista Fyhr for informing us about this earthstar in her flowerbed.

\section{References}

Carlsson, R. \& Hæggström, C.-A. 2005: Geastrum rufescens in the Alland Islands, SW Finland. - Karstenia 45: 63-68.

DMS 2004: Danish Mycological Society, Red List of fungi. - http://www.svampe.com/

ERL 2001-2002: Punane Raamat, seened. (Estonian Red List of fungi.) - http://www.zbi.ee/punane/liigid/ seened.html

Gärdenfors, U. (ed.) 2000: Rödlistade arter i Sverige 2000. The 2000 Red List of Swedish Species. - 397 pp. ArtDatabanken, SLU, Uppsala.

Hæggström, C.-A. 1983: Vegetation and soil of the wooded meadows in Nåtö, Åland. - Acta Bot. Fennica 120 $1-66$.

Hæggström, C.-A. 1997a: The Gasteromycetes of the Aland Islands, SW Finland: an annotated checklist. Karstenia 37: 11-18.

Hæggström, C.-A. 1997b: Bovista pusilliformis found in Finland. - Memoranda Soc. Fauna Flora Fennica 73: 59-64.

Hæggström, C.-A. \& Carlsson, R. 1999: The earthstar Geastrum triplex Jungh. found on Åland, SW Finland. - Memoranda Soc. Fauna Flora Fennica 75: 1-5.
Hämet-Ahti, L., Suominen, J., Ulvinen, T. \& Uotila, P. (eds.) 1998: Retkeilykasvio (Field Flora of Finland), Ed. 4. - 656 pp.Finnish Museum of Natural History, Botanical Museum. Helsinki.

Järva, L. 1999: Geastrum berkeleyi Massee. - In: Parmasto, E. (ed.), Distribution maps of Estonian fungi 2. Protected species and species of the Estonian Red Data Book. Distribution Atlas of Estonian Fungi 2, nr. 59. Tartu.

NRL 2004: The Mycological Herbarium, Oslo. Taxa in the mycological herbarium. - http://www.toyen.uio.no/ botanisk/botmus/sopp/redalpha.htm

Rassi, P., Alanen, A., Kanerva, T. \& Mannerkoski, I. (eds.) 2001: Suomen lajien uhanalaisuus 2000. (The 2000 Red List of Finnish species.) - Ympäristöministeriö \& Suomen ympäristökeskus, Helsinki. 432 pp.

Schwik, J., Wiesendorf, H. \& Westphal, B. 1999: Rote Liste der gefährdeten Großpilze Mecklenburg-Vorpommerns. 2. Fassung - http://www.uni-greifswald.de/ mycology/rl-mv.htm

Sunhede, S. 1989: Geastraceae (Basidiomycotina). Morphology, ecology, and systematics with special emphasis on the North European species. - Synopsis Fungorum 1: 1-534. Fungiflora, Oslo.

Sunhede, S. 1997: Geastraceae Corda. - In: Hansen, L. \& Knudsen, H. (eds.), Nordic Macromycetes 3: 341345. Nordsvamp, Copenhagen. 